\title{
Underwater archaeobotany: plant and wood analyses from the Vrouw Maria, a 1771 shipwreck in the Finnish Baltic Sea
}

\author{
Mia Lempiäinen-Avci ${ }^{1}$ (1) $\cdot$ Tuuli Timonen $^{2} \cdot$ Pirkko Harju $^{2} \cdot$ Riikka Alvik $^{3}$
}

Received: 29 January 2021 / Accepted: 30 April 2021 / Published online: 11 May 2021

(c) The Author(s) 2021

\begin{abstract}
Archaeobotanical analyses together with historical records can provide unique information about the cargoes and histories of sunken ships, which are found as wrecks at the bottom of the seas all over the world. An interdisciplinary research project was undertaken on the Vrouw Maria (Lady Mary), a Dutch wooden two-masted merchant ship that sank on October 9th in 1771 in the Finnish Baltic Sea. She rested at a depth of $41 \mathrm{~m}$ and was in good condition when discovered. Based on written sources and archaeological research, the ship was carrying a valuable cargo including, for example, sugar, dyes, cloth, porcelain, wood and goods that the Russian nobility had ordered. Among them were paintings that the Russian Empress Catherine the Great (1729-1796) had bought at an auction in Amsterdam. Samples from four wooden barrels and from one wooden packing crate among the ship's cargo were investigated. Botanical analysis revealed products such as stimulants, dyes and fruits originating from the Mediterranean, India, Africa and South America. One of the most intriguing finds from the cargo was Indigofera tinctoria L. (true indigo), a valuable dye plant. Our paper presents the botanical data analysed from the barrels and summarizes the plants mentioned in the historical records on the cargo of the Vrouw Maria.
\end{abstract}

Keywords Finland · Merchant ship · Plant remains · Indigofera tinctoria $\cdot$ Underwater archaeology $\cdot$ Late 18 th century

\section{Introduction}

Underwater conditions generally preserve organic material and therefore shipwrecks can provide abundant remains of fruits, nuts, spices and other plant products seldom found on land sites (Haldane 1990). Therefore, botanical remains from shipwrecks offer interesting insights into vessels and their voyages. The remains might have been part of either the cargo of traded products, or those meant for consumption on board (Moolhuizen 2009). Additionally, pollen, seed, fruit, moss, wood and fibre finds can answer questions regarding

Communicated by K.-E. Behre.

Mia Lempiäinen-Avci

mialem@utu.fi

1 Biodiversity Unit, University of Turku, 20014 Turun yliopisto, Finland

2 Botany Unit, Finnish Museum of Natural History, University of Helsinki, Pohjoinen Rautatiekatu 13, 00014 Helsinki, Finland

3 University of Helsinki, Archaeology, Yliopistonkatu 3, 00014 Helsinki, Finland ship building techniques and materials used, caulking, provenance, navigation routes, cargoes, provisions, victualling (food) and the role of a vessel (Haldane 1993; Badura et al. 2013; Deforce et al. 2014; Vermeersch and Haneca 2015).

The cold, brackish Baltic Sea is known to be one of the best locations in the world for preservation of wooden wrecks (for example, Leino et al. 2011; Eriksson and Rönnby 2012). Marine organisms that consume wood, such as the Teredo navalis L. (naval shipworm), are absent from the Baltic Sea. Therefore, the hulls of wooden wrecks can stay intact with their masts standing for hundreds of years on the sea floor, as Eriksson and Rönnby (2012) have noted. One example of the well-preserved shipwrecks found in the Baltic Sea is a Dutch merchant ship, the Vrouw Maria (Fig. 1). She was on her way from Amsterdam to St. Petersburg in October 1771. After mis-navigating in a storm, she lost her way in the Saaristomeri (archipelago of islands off southwest Finland), hit a hidden rock twice and lost her rudder. This area is full of rocky islets, and even today, difficult to navigate. At that time, the nearby islands Borstö and Trunsö were inhabited all year around, and one of the occupations of the local inhabitants was to keep watch in case of shipwrecks. The local fishermen helped in salvaging the 


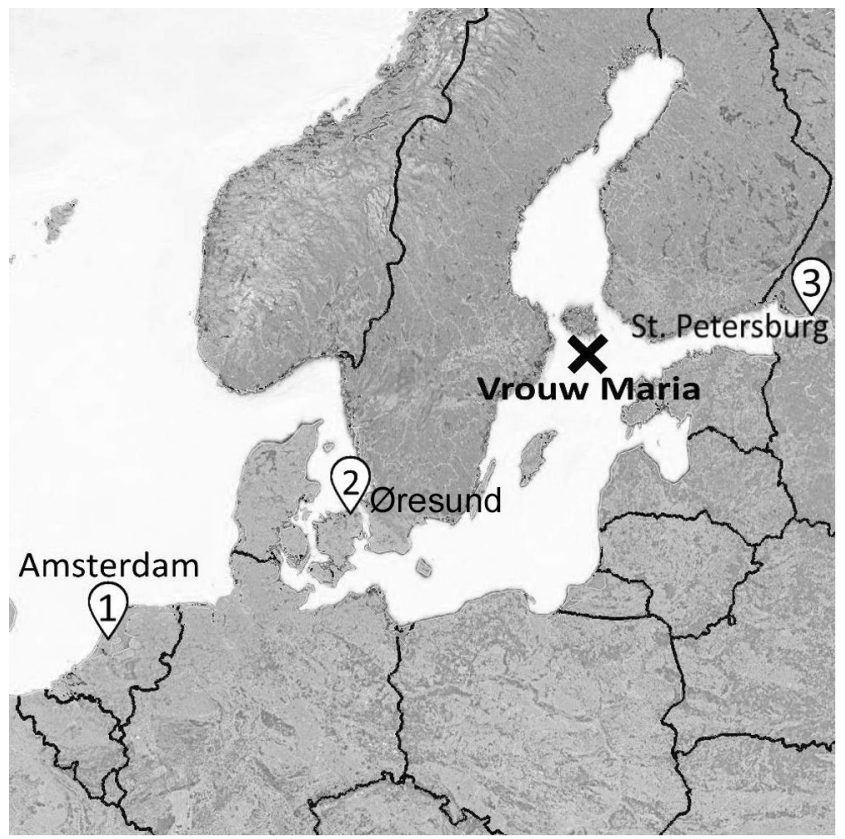

Fig. 1 Map of the last journey of the Vrouw Maria. She was on her way from Amsterdam to St. Petersburg. 1 her journey started on 5.9.1771 from Amsterdam, 2 on 23.9.1771, she passed through the Øresund, $\mathbf{x}$ she ran aground on 4.10.1771, and sank on 9.10.1771 in the Saaristomeri, 3 her destination was St. Petersburg

contents of the ship for several days, but on the fifth day of the salvage operation, on October 9th, the ship finally sank to a depth of $41 \mathrm{~m}$. The crew and the salvaged cargo were taken to Åbo (Turku) for the maritime declaration and other official procedures (Leino et al. 2011; Alvik et al. 2014).

The shipwreck was located $\left(59^{\circ} 46^{\prime}, 21^{\circ} 47^{\prime}\right)$ after several search attempts in 1999. After that, several research projects followed. The archaeological underwater research described in this article took place between the years 2009-2012 by the Finnish National Board of Antiquities' Maritime Archaeology Unit, now called Museovirasto (Finnish Heritage Agency), as part of the Vrouw Maria underwater project (Alvik et al. 2014). During the underwater research, it became clear that it would not be possible to dive into the cargo hold for safety reasons, as it was still full of barrels and crates of the cargo, which posed a risk of the divers being stuck in the structures of the wreck. Also, it was feared that the diving could cause damage to the fragile contents of the hold. Many of the barrels and crates were already partially damaged, but their shapes were still visible. Unfortunately, it was not possible to take samples of the barrels for wood taxon identification due to the conditions. However, some artefacts could be raised and samples collected from the barrels and packing crates of the cargo for study. Raised artefacts included, for example, clay pipes, glass discs and a barrel lid. Among the most interesting botanical items recovered from the cargo hold are rolled tobacco leaves (Nicotiana tabacum L.; Timonen 2011).

Economic plants have been recovered from many shipwrecks all around the world. The oldest is the late 14th century BC Uluburun wreck from southwestern Turkey, shedding light on the late Bronze Age trade (Bass 1987). Some of the most intriguing botanical finds from wrecks from the North Sea and the Baltic Sea are for example Piper nigrum L. (black pepper), Oryza sativa L. (rice) and Cucumis sativus L. (cucumber) that were discovered from a 17th century shipwreck in the Wadden Sea off the Dutch coast (Moolhuizen 2009). In addition, Coffea arabica L. (unroasted coffee beans), Theobroma cacao L. (cocoa beans) and Saccharum officinarum L. (sugar cane) were recovered from an 18 th century wreck found in the Wadden Sea (Kuijper and Manders 2009). Also, bulbs of Allium cepa L. (onion) and Allium sativum L. (garlic), have been identified from the 15th century copper wreck near Gdansk in Poland (Badura et al. 2013).

The aim of this paper is to provide an insight into the cargo of the Dutch merchant ship Vrouw Maria. We have analysed the botanical material obtained from the wooden barrels and compared the results to historical records about the cargo. These botanical finds add to our knowledge about goods which were traded overseas, opening new avenues for discussions in underwater archaeology and in archaeobotany.

\section{Written sources on the cargo}

A number of studies already carried out on historical documents reveal many details about the Vrouw Maria. For example, the cargo owners, cargo contents, insurers, the events related to the accident, rescue attempts and the salvaged goods are known about (for example, Ahlström 2000a; Gelderblom 2003; Tikkanen 2006; Leino et al. 2011; Alvik 2013). One of the most important sources about maritime trade in the Baltic are the Øresundtoldregnskab (Danish sound toll registers) of dues paid to Denmark for passage through the Øresund between Denmark and Sweden. These describe the shipping and trade by every vessel that sailed in or out of the Baltic through the sound from 1497 to 1857 (Gøbel 2010). The entries contain a huge amount of information. Each vessel passing through the Øresund was listed with its home port, nationality, destination, the name and domicile of its captain, its cargo specified in more or less detail, and finally the customs duties paid.

From these records it is known that the Vrouw Maria started her journey on the 5th of September 1771 and passed the Øresund on the 23rd. Her cargo consisted of luxury items, such as Dutch works of art bought by the Russian empress Catherine the Great and the Russian prince Gallitzin. According to the cargo manifest, there were also sugar, dyes, zinc, mercury, silver, cloth, clay pipes and provisions 
such as cheese, butter, herring and cod (Gelderblom 2003). From the archaeobotanical point of view, interesting items listed in the registers are sugar, madder, brazilwood, indigo, raw cotton and figs (for example, Tikkanen 2006; Alvik 2012; http://www.soundtoll.nl).

The list of salvaged goods provides another important written source about the cargo of the Vrouw Maria. The document written by the salvage company reveals items such as flower bulbs and seeds, Spanish snuff, pipe tobacco, tea, coffee and a bunch of moss (Tikkanen 2006; Alvik 2011). Additionally, a small amount of indigo was salvaged (Tikkanen 2006). Also, one curiosity on the list from the botanical perspective is a "textile or cloth made of nettle" (Tikkanen 2006).

The third written source in tracing the cargo of the Vrouw Maria is the maritime declaration which was given by the captain, Reynoud Lourens, in the courtroom at Ảbo in Finland on the 23rd December 1771. In the declaration Lourens claims, that: "The coffee beans caused a blockage to the bilge pumps of the ship and pumping was impossible and therefore the ship sank" (Ahlström 2000b, p 7; Tikkanen 2006). Part of the coffee was salvaged and sold in St. Petersburg in the spring of 1772 by a newspaper advertisement (Gelderblom 2003, p 111). The fourth source is the list of rescued items sold in an auction, but this does not contain any botanical items.

\section{Materials and methods}

Marine archaeologists collected the samples for botanical analyses from the barrels and from a packaging crate by using a tube sampler to collect organic material. Particular barrels and crates were sampled via two cargo hatches. The seawater that was also drawn into the sampler acted as a natural preservative for the brittle organic material. From the tube sampler, the organic material and seawater was transferred to tightly sealable plastic boxes.

Before the analyses, it was important to maintain conditions similar to those on the seabed. Therefore, the samples were stored in a refrigerator at $4{ }^{\circ} \mathrm{C}$ and protected from light. The samples were sent for analysis to the Herbarium (TUR) at the University of Turku and to the Botanical Unit in the Finnish Museum of Natural History (HEL) at the University of Helsinki.

Altogether five samples were analysed for their botanical content, four from the wooden barrels and one from a wooden crate. All samples were very different in appearance and composition. The seawater in sample 1 (grape barrel) was greenish, and the organic material composed of wellpreserved fruits ca $1.5 \mathrm{~cm}$ in size, fruit stones, seeds and leaves. The seawater in sample 2 (barrel 3) was reddish but clear, with three types of plant remains floating in the water: small fragments resembling wood sized ca. $2-5 \mathrm{~mm}$, seeds and yellow-greenish material that looked like hay. The seawater in sample 3 (coffee barrel) was light blue, and the organic material in the sample was dominated by ca. 1.5 $\mathrm{cm}$ sized white-greyish seeds and blue lumps sized ca. 1 $\mathrm{cm}$. Sample 4 (wooden crate) consisted of clear seawater with floating material resembling hay and wood. In sample 5 (dye barrel) the seawater was blue with dark blue pieces (size $1.5 \mathrm{~cm}$ ) floating in it together with green fruits (size $1.5 \mathrm{~cm}$ ). The seawater of each of the samples was poured through $0.5 \mathrm{~mm}$ and $0.25 \mathrm{~mm}$ mesh sieves after which the retained botanical material was sorted and identified under a stereomicroscope. The plant nomenclature in this study follows The world checklist of vascular plants (2021).

\section{Analyses based on morphology and anatomy}

The identification of seeds, fruits, berries and leaves based on their morphology was done by using the reference collection of modern plants at Turku Herbarium (TUR) and at Kew Gardens, UK and literature (Beijerinck 1947; Cappers et al. 2006). In addition, personal communication with archaeobotanists in Europe resulted in further plant remains being identified from the material. Anatomical identifications of wood and some vascular plant stems as well as leaves were made by using the reference collection of the Botanical Unit in Helsinki (HEL), reference slides prepared for the project and literature (Schweingruber 1990; Gale and Cutler 2000).

\section{Results}

The results are presented in Table 1. The plant remains in all samples were well preserved, for example the fruits and berries still had fruit flesh and skins, and they were still attached to the stems and their colours were bright. Some fruits and berries looked so fresh, as if they had been recently collected and stored in the barrels. Apart from some charred grape pips, all the plant remains were preserved waterlogged, but not mineralized. The blue lumps in the samples appeared to be of a densely pressed powdery substance, that bled colour to the water and to the fruits, berries and other plant remains. Also, when handling the lumps, they detached blue colour to rubber gloves, tweezers and graph paper.

Sample 1-grape barrel-totalled nine plant taxa. A small number of blue lumps was also noticed. The majority of the plant remains found in the sample were Vitis vinifera L. (grape) pips, but one complete fruit, flowers, fruit skins and stalks (pedicels) were also present. Most of the grapes were green, but some were purple. One berry, a leaf, seeds, stalks and a branch of Myrtus communis L. (myrtle) were found. Wood taxa present were Paubrasilia echinata (Lam.) Gagnon \& H.C. Lima \& G.P. Lewis, formerly known as 
Table 1 The botanical analyses from the Vrouw Maria

\begin{tabular}{|c|c|c|c|c|c|c|}
\hline Sample no. and context & & 1, Grape barrel & 2, Barrel 3 & 3 , Coffee barrel & 4, Crate & 5, Dye barrel \\
\hline \multicolumn{7}{|l|}{ Useful/cultivated } \\
\hline Coffea arabica, seed coat/bean/pedicel & Arabica coffee & & & $900 / 2 / 113$ & & \\
\hline Indigofera tinctoria, blue lump (g)/leaf & True indigo & 0.16 & & $0.429 / 1$ & 0.02 & 34 \\
\hline Myrtus communis, berry/seed & Myrtle & $1 / 9$ & 14 & & & 12 \\
\hline leaf/branch/stalk & & $1 / 1 / *$ & $2 / 1 / *$ & & $/ / *$ & \\
\hline Rubia tinctorum, root, rhizome & Madder & & $* *$ & $* * *$ & $* * *$ & $*$ \\
\hline Vitis vinifera, $\mathrm{pip} /$ fruit/fruit skin & Grape & $422 / 1 / 102$ & 1 & 3 & & $124 / / 1$ \\
\hline pedicel/charred pip/flower & & $175 / 5 / * *$ & $12 /$ & $/ 2 /$ & & 4 \\
\hline \multicolumn{7}{|l|}{ Weed (seeds) } \\
\hline Alchemilla sp. & Lady's mantle & & 4 & & & \\
\hline Brassica sp., Brassica/Raphanus & Turnip/radish & & 1,1 & & & \\
\hline Camelina sativa & Gold of pleasure & & 1 & & & \\
\hline Chenopodium album & Fat hen & 1 & 3 & & & \\
\hline Fallopia convolvulus & Black bindweed & & 4 & & & \\
\hline Lamium sp. & Dead nettle & & 1 & & & \\
\hline Lythrum salicaria & Purple loosestrife & & 1 & & & \\
\hline Medicago sp. & Medick & & & & & 1 \\
\hline Scleranthus anпииs & Annual knawel & & 3 & & & \\
\hline Setaria sp. & Bristle grass & & 1 & & & \\
\hline Sonchus oleraceus & Sow thistle & 1 & & & & \\
\hline Stellaria media & Chickweed & & 3 & & & \\
\hline Trifolium sp. & Clover & & 1 & & & \\
\hline Veronica sp. & Speedwell & & 1 & & & \\
\hline Viola sp. & Violet & & 4 & & & \\
\hline Poaceae, leaf & Grasses & & $* * *$ & & $* *$ & \\
\hline \multicolumn{7}{|l|}{ Indeterminate } \\
\hline leaf (cf. Myrtus communis) & & 2 & & & & \\
\hline leaf/seed/straw & & $/ 3 / 1$ & $1 / 2 / * * *$ & & & \\
\hline Stalk/thorn & & $*$ & $* / * * *$ & & & \\
\hline cf. Fabaceae, pod & & & $* *$ & & & $* * *$ \\
\hline Dicotyledonous herb, stem & & & & & 1 & \\
\hline Total no. of plant remains & & 725 & 42 & 1,021 & 1 & 132 \\
\hline \multicolumn{7}{|l|}{ Wood } \\
\hline Paubrasilia echinata & Brazilwood & $*$ & $*$ & & $*$ & \\
\hline Fagus sp. & Beech & $*$ & & $*$ & $*$ & \\
\hline Picea sp./Larix sp. & Spruce/Larch & $*$ & $*$ & & $*$ & $*$ \\
\hline Quercus sp. & Oak & $*$ & & & $*$ & \\
\hline Unidentified wood & & $* *$ & $* * *$ & & $* * * *$ & $* *$ \\
\hline \multicolumn{7}{|l|}{ Other remains } \\
\hline Spirulina sp. & Seaweed & & $* * *$ & & $* *$ & \\
\hline Algae & Seaweed & & $* *$ & & & \\
\hline Mollusca/Bivalvia & Shells & $*$ & $* *$ & & & $* *$ \\
\hline Daphnia sp. & Water flea (adult) & & & 2 & & \\
\hline Insecta, insect fragments & & $1 / 2$ & $1 / 2$ & & & 1 \\
\hline Animal fur & & 1 & 1 & & & \\
\hline Fibre & & & $* *$ & & $* *$ & \\
\hline Paint & & & & & & $* *$ \\
\hline
\end{tabular}

The numbers given refer to the actual counted amounts

* refers to relative frequencies of recorded fragments per sample: ${ }^{*} 1-5,{ }^{* *} 5-20,{ }^{* * *} 20-50,{ }^{* * * *} 50-100$ 
Caesalpinia echinata Lam. (brazilwood), Fagus sp. (beech), Larix sp./Picea sp. (larch or spruce) and Quercus sp. (oak). Other remains in the sample were sea shells (Mollusca/ Bivalvia), one insect, fragments of insects and animal fur, but these remains have not yet been further analysed.

Sample 2-barrel 3-was dominated by a spectrum of weed seeds from taxa common in arable fields and ruderal places. Myrtle seeds, as well as charred and uncharred grape pips were also present. The sample included plenty of small fragments which could be identified as rhizomes and roots of Rubia tinctorum L. (madder) and brazilwood, both used for dye. Some of the wood fragments were larch/spruce, while most of the studied wood fragments were so small that they were identifiable only as dicotyledonous trees. The floating material resembling hay came from monocotyledonous flowering plants, Poaceae (grasses). In addition, leaves, stalks and one branch of myrtle were present. The plant remains in the sample also included a leaf, seeds, straw, stalks, thorns and legume pods, all of which remained unidentified. Other material included seaweeds (Algae and Spirulina sp.) together with bivalve shells, unidentified complete insects and some insect fragments, animal fur and fibres.

Sample 3-coffee barrel-was dominated by whitegreyish seed coats of Coffea arabica L. (coffee beans), among which were also two intact beans preserved complete (Fig. 2). Similar blue lumps as were found in sample 1 were also present in this sample. The blue lumps had also coloured the seawater in the sample. Each lump was studied under a microscope and on the top of one lump, a leaf was preserved. Its lower surface was covered with fine short hairs, a distinctive feature of the dye plant Indigofera tinctoria $\mathrm{L}$. (true indigo). This feature confirmed that the blue lumps in the samples were made of indigo (Fig. 3). Now it was also clear that the blue powdery substance that had coloured the water and the plant remains was indigo.

A large amount of root or rhizome fragments of Rubia tinctorum (madder) were also identified in the sample. Other remains identified were leaves of grasses fragments of beech wood. In addition, both charred and uncharred grape pips were present in the sample. Faunal remains in the sample included adult Daphnia sp. (water fleas).
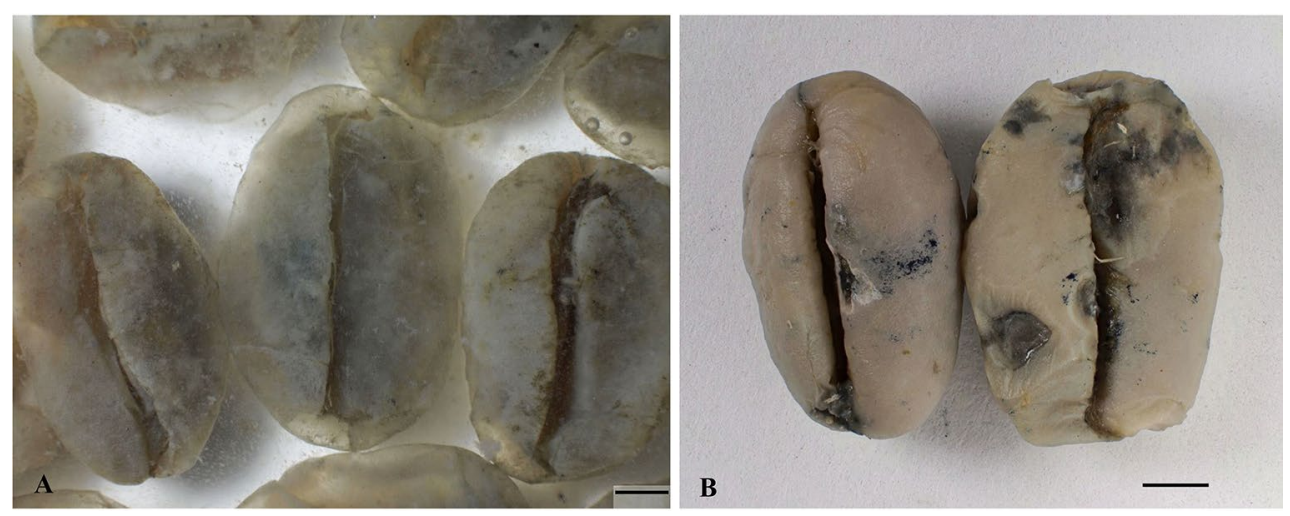

Fig. 2 a Outer seed coats of coffee beans, b two intact beans were preserved complete, scale bars 2 mm (photos by Mia Lempiäinen-Avci)
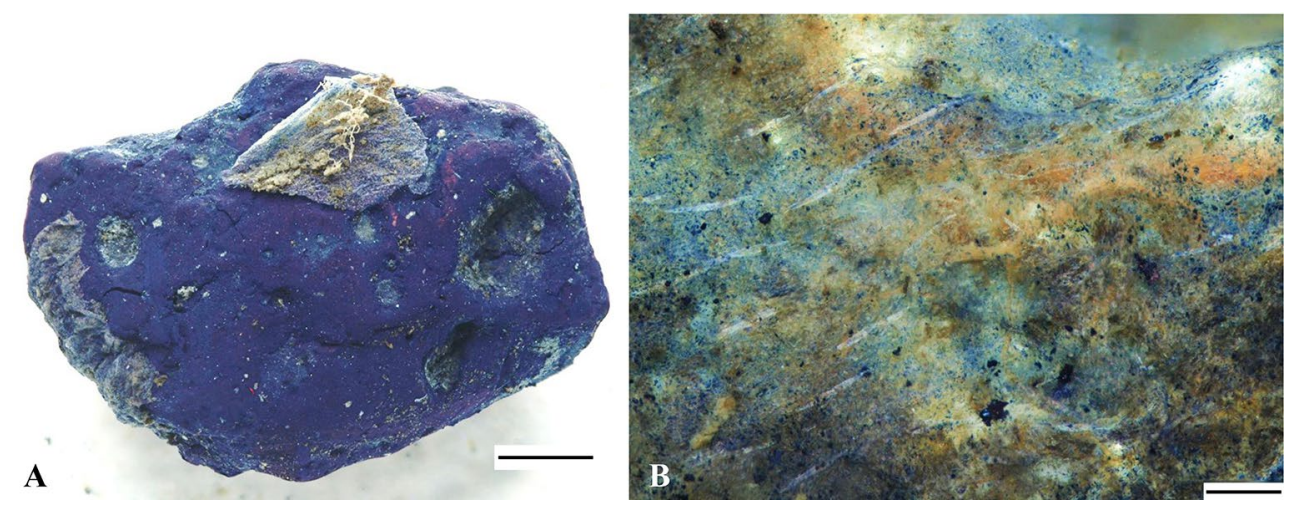

Fig. 3 a Fragment of indigo dye and a small fragment of a leaf on top, scale bar $1 \mathrm{~mm}$, b fine short hairs on the lower surface of the leaf, a distinctive feature of Indigofera tinctoria; scale bar $0.2 \mathrm{~mm}$ (photos by Mia Lempiäinen-Avci) 
Sample 4-wooden crate-included some tiny indigo pigment lumps. Other remains noted were madder root or rhizome fragments, while the pieces of wood were identified as brazilwood, beech, larch/spruce and oak. Stalks of myrtle as well as a stem of a dicotyledonous herb were identified. Also, Spirulina seaweed and some unidentified fibres were noted.

Sample 5-dye barrel - included a large amount of indigo lumps, remains of myrtle and grapes. A small amount of madder, wood fragments of either spruce or larch and unidentified legume pods were also found. Besides these, the sample included one complete insect, shells and fragments of paint.

\section{Discussion}

The stable and anaerobic conditions at the depth of $41 \mathrm{~m}$, and the low salinity of the Baltic Sea offered excellent preservation circumstances for the organic materials in the cargo. The decomposition process had literally stopped, yielding plant specimens far better preserved and fresh looking, than are usually recovered from archaeological contexts. The botanical analyses, based on the morphological and anatomical features of the plant remains, allowed for wider taxonomic identification, resulting in unique information about the cargo of the Vrouw Maria.

\section{Plant products from the cargo}

Indigo (nil in Hindi) belongs to the Fabaceae, and over 300 species of the genus Indigofera are known, many of which yield the pigment indigo, but two of the most important ones are I. tinctoria L., native to the tropics in India and Asia, and I. suffruticosa Mill., which is native to the tropical Americas. Dyers in India and southeast Asia have used indigo for thousands of years and it has been among the luxury goods traded possibly even already by the 3rd millennium вс. For example, the cloths wrapping ancient Egyptian mummies were dyed with this spectacular plant (Balfour-Paul 2016). Furthermore, ancient Greeks and Romans called the plant indicum, meaning a product of India, thus indicating the import of indigo pigment by the Graeco-Roman world (Buchanan 2003; Balfour-Paul 2016). No other dye plant has had such a worldwide success as "the king of dyes". The extraction process of the dye involves several steps beginning with soaking the harvested indigo crop and finally resulting in a paste. This paste is subsequently pressed into dye cakes and dried, and in this form indigo was traditionally traded and exported (Nesbitt 2013). The advent of synthetic dyes in the 19th century dramatically decreased the demand for natural indigo. Previous underwater archaeobotanical finds of indigo have come from a Spanish galleon that was wrecked in the Caribbean in 1640 (Balfour-Paul 2010).

Paubrasilia echinata and related species (brazilwood, in Portuguese pau-brasil), is a tree in the Fabaceae which is native only to Brazilian coastal forests. It may reach up to $15 \mathrm{~m}$ in height and the branches, leaves and fruits, which are woody seedpods, are all covered with small thorns (Lewis 1998). The timber became highly valued in Europe in the 16 th century as the source of a red dye called brazilin. After felling, the timber was prepared locally, as only the heartwood was used for dye. Therefore, the bark, branches and outer layers were removed before transport across the Atlantic. The brazilwood logs were traded to Europe, where they were reduced to fine powder, which could be mixed with water to create the dye (Dodge 2018). Brazilwood identified from the Vrouw Maria together with written historical sources confirm that this now endangered tree species was on the way to St. Petersburg.

The genus Coffea comprises ca. 40 species of which $C$. arabica L. (Arabian coffee) is endemic to the southwestern highlands of Ethiopia, being the oldest known species of coffee to be cultivated for its berries. Today, it is the most widely cultivated coffee in the world. During the 1700s the plant was brought to the New World and introduced there, for example to Brazil in 1752 (Wild 2004). However, the origins of the coffee beans found from the Vrouw Maria are not clear. As there are other items originating from Brazil in the cargo, it may well be that the coffee beans are also from there. Another underwater find of coffee beans came from an 18th century wreck off the Netherlands (Kuijper and Manders 2009). There are terrestrial archaeological finds of coffee beans from Prague, Czech Republic, dating to the 16-17th centuries (Beneš et al. 2012), from Stralsund, Germany (Wiethold 2005) and from Oulu, Finland (Lempiäinen 2006) the last two from the 19th century.

Myrtus communis L. (myrtle) is an aromatic evergreen shrub native to the Mediterranean region. It has many uses due to its aromatic properties, edible fruit, fragrant flowers and evergreen leaves. Essential oils are extracted from the leaves, while mature fruits are used in liquor and medicine. In the ancient Greek and Roman world, myrtle was dedicated to Aphrodite and Venus, and by Christians to the Virgin Mary (Šsoštarić and Küster 2001; Dafni 2016 and references therein). Myrtle was an essential element in many ceremonies, including weddings, funerals and the ancient Olympic Games. Also, myrtle wreaths were used to crown priests, heroes and generals (Dafni 2016 and references therein). From the barrels of the Vrouw Maria leaves, berries and branches of myrtle were found. Therefore, it is to be assumed that fresh bundles or living plants of myrtle were being transported in the ship. However, for what purpose the plant was exported to Russia, remains unknown. Previous archaeological myrtle seeds have been found, for example, 
from a Bronze Age well in Italy (Sabato et al. 2015), from a well in a Gallo-Roman farm in France (Figueiral et al. 2010) and from a Roman villa in Croatia (Šoštarić and Küster 2001).

The genus Nicotiana comprises ca. 70 species, of which the main ones used for tobacco are N. tabacum L. and $N$. rustica $\mathrm{L}$., both native to the Americas. Eleven tobacco rolls of $N$. tabacum leaves were found in the captain's chest from the Vrouw Maria. Additionally, Nicotiana leaves have been recovered from the shipwreck Borstö I (previously called St. Michel), which sank around the year 1747 near the island of Borstö in the archipelago of Finland. The ship was on her way to St. Petersburg (Alvik 2013). However, the species of the tobacco leaves from Borstö I has not been studied in detail (Alvik 2021, pers. comm.). Tobacco rolls were also found from the Kronan, a 1660s shipwreck in the Baltic Sea, off the east coast of Öland, Sweden (Einarsson and Mörzer Bruyns 2003).

Seeds of N. tabacum have been found from a cesspit dated to the 17-18th century in the Czech Republic (Preusz et al. 2015). Additionally, N. tabacum and N. rustica seeds have been identified from several Swedish towns, both dated to the sixteenth-eighteenth century (Heimdahl 2014). Also, $N$. rustica seeds have been found in Denmark, dated to the seventeenth century (Karg 2007). By the 17th century pipe tobacco, snuff and cigarettes were all commonly used in Europe. Pipe tobacco refers to coarsely cut tobacco leaves suitable for smoking in pipes, while for paper rolled cigarettes tobacco leaves were traded uncut. Snuff, on the contrary, is powdered tobacco. Speaking for the importance of smoking is the fact that clay pipes of Dutch origin were recovered from the cargo of the Vrouw Maria, and hundreds of clay pipes still remain there (Alvik 2013).

Rubia tinctorum L. (madder) is indigenous to southern Europe and the Middle East, but it is cultivated in most parts of the world. The genus Rubia contains over 10,000 species, of which $R$. tinctorum is the most commonly cultivated one. The plant is also known as dyer's madder, as red dye can be obtained from the roots and leaves. Its reddish roots have been used for dyeing textiles since ca. 4000-3000 BC, based on dyed cotton threads found in Dhuweila, Jordan (Chenciner 2000). Madder was an important traded commodity for the ancient Romans. The dye is made from the roots of two year old plants, which are dried after harvesting and then peeled and crushed to a powder (Gale and Cutler 2000). Besides its importance in dyeing, madder roots have also been used in the treatment of kidney and bladder stones. However, they are known to be genotoxic, as a carcinogen called lucidin is produced in the roots when crushed (Nakanishi et al. 2005), a procedure for obtaining more pigment from them.

Remains of madder root have been found, for example in Anglo-Scandinavian deposits in Coppergate, York and
Anglo-Saxon London, UK (Hall 1996; Walton Rogers 1997). The origin of the madder found from the Vrouw Maria's cargo remains unknown. However, it is known that at this time France and The Netherlands were the largest producers of madder. It was also cultivated in Russia, in the Caucasus and along the coast of Caspian Sea, but the quality was less than that of the French and Dutch product (Chenciner 2000). It is possible that it was then known that Russian madder did not meet the standards required by Empress Catherine the Great, and a higher quality product was imported to Russia.

The rest of the identified botanical remains are listed here as weeds, even though some of them are from plants that have economic value and are cultivated. Altogether 16 different taxa were identified, and they almost solely derive from sample 2 (barrel 3). Sea borne contamination is not an explanation for the presence of weeds, as the sample was collected from inside a barrel and the Vrouw Maria lies on the sea bed $41 \mathrm{~m}$ deep in the outer Finnish archipelago. Hence they represent plants, which were collected and intentionally placed in the barrel. The assemblage consists of plants from pastures, meadows and arable land and they reflect the vegetation at the site where they were collected. Weeds are known from other shipwrecks as well. For example, Robinson and Aaby (1994) have noted in their studies on the Gedeby shipwreck that an assemblage of various plant taxa may derive from fodder for the livestock on board, or even from its dung. However, there is no evidence that the Vrouw Maria was carrying any animals on her last journey. Haldane (1993) and Ramsay (2010) have suggested that weeds found from shipwrecks may represent plants used as dunnage, a protective matting used for the cargo, or from plants that were used for packing and sealing. Keeping in mind the valuable goods in the cargo of the Vrouw Maria, the weeds may well have come from plants that were used for padding fragile objects in the barrels.

Rather small amounts of wood fragments were present in the samples, and except for the brazilwood, they represent common coniferous and deciduous trees in northern Europe and in the Baltic Sea area. Only brazilwood was part of the cargo, as it is listed in the historical Sound Toll Records. Therefore, it can be assumed that the wood fragments of oak, beech and spruce/larch originate from raw material used in the ship structure, barrels, wooden items and so on. According to Haldane (1993), charred remains may be from remnants of the food that the crew had consumed on board. This domestic waste was then discarded into a fireplace and charred. However, the charred grape pips from the Vrouw Maria were found inside the barrels, so interpreting them as domestic waste does not seem a viable explanation.

Barrels made from wooden staves and bound by hoops were very common containers throughout history (Loewen 1992). Even though the wood taxa of the barrels from the Vrouw Maria could not be analysed, those from other 
shipwrecks have been studied. Quercus (oak) and Pinus (pine) were the most common, however, barrels were also made using Salix (willow), Fagus (beech), Castanea (chestnut), Fraxinus (ash), Ulmus (elm) and Corylus avellana (hazel) (Loewen 1992; Schoute 2017).

\section{Plant material and written sources}

By comparing the different written sources about the cargo of the Vrouw Maria, the botanical data and items lifted from the cargo, a clearer picture of the traded items and other goods on board can be reached. The results of the combined data are presented in Table 2.

The dyes brazilwood, indigo and madder were officially listed traded materials in the cargo, as they appear in the Sound Toll Records (STR) and their weight and value is also noted in the records. These three dyestuffs were also identified in the botanical analyses. However, the records of the salvaged goods coffee, pipe tobacco, Spanish snuff, tea and tobacco leaves were not considered as part of the official cargo as they are not mentioned in the STR. The reason for this may be that the nobility could order goods privately and these were exempt from customs duties. Also, customs documents often include entries for "miscellaneous merchandise" which could include anything from luxury items such as art and books to consumable everyday products. Besides, the captain had a right to trade for his own profit, and the most valuable goods were usually kept in the captain's cabins above the water line. Some of the goods were privately ordered, as can be seen from the list of salvaged goods, as there are names of the owners in St. Petersburg. The remarks in the logbook written by Captain Lourens together with the archaeological research indicate that the salvaged goods came from the captain's cabin and were intended for private use. However, not all of the coffee was salvaged, as an abundance of coffee beans was found in the samples. Tobacco leaves are not mentioned at all in the historical sources, but some leaves were lifted from the cargo during the archaeological research on the wreck. Among the useful plants, only grapes and myrtle are present in the botanical data, whereas cotton, figs, moss, seeds and bulbs are part of the salvaged goods list. Also, sugar is listed in the STR and later in the maritime declaration it was noted that the seawater tasted sweet (Ahlström 2000a). The unnamed seeds mentioned in the salvage list are presumably of either decorative or economic plants.

\section{Conclusions}

The botanical data together with the written sources confirm that the cargo of the Vrouw Maria contained valuable dyestuffs. However, in the course of the salvage operation,
Table 2 The botanical data compared to the historical records of the Vrouw Maria

\begin{tabular}{|c|c|c|c|c|c|c|}
\hline Taxa/Plant item & $\begin{array}{l}\text { Botanical } \\
\text { analysis }\end{array}$ & $\begin{array}{l}\text { Sound toll } \\
\text { registers }\end{array}$ & $\begin{array}{l}\text { List of } \\
\text { salvaged } \\
\text { goods }\end{array}$ & $\begin{array}{l}\text { Maritime } \\
\text { declaration }\end{array}$ & Lifted items & Amount in STR \\
\hline \multicolumn{7}{|l|}{ Dyes } \\
\hline Brazilwood (kg) & $\mathrm{xxx}$ & $\mathrm{x}$ & & & & 1,998 \\
\hline Indigo (kg) & $\mathrm{x}$ & $\mathrm{x}$ & $\mathrm{x}$ & & & 1,373 \\
\hline Madder (kg) & $\mathrm{x}$ & $\mathrm{x}$ & & & & 7,642 \\
\hline \multicolumn{7}{|l|}{ Stimulants } \\
\hline Coffee & $\mathrm{x}$ & & $\mathrm{x}$ & $\mathrm{x}$ & & \\
\hline Pipe tobacco & & & $\mathrm{x}$ & & & \\
\hline Spanish snuff & & & $\mathrm{x}$ & & & \\
\hline Tea & & & $\mathrm{x}$ & & & \\
\hline Tobacco & $\mathrm{x}$ & & & & $\mathrm{x}$ & \\
\hline \multicolumn{7}{|l|}{ Other useful plants } \\
\hline Cotton $(\mathrm{kg})$ & & $\mathrm{x}$ & & & & 519 \\
\hline Figs & & & $\mathrm{x}$ & & & \\
\hline Grapes & $\mathrm{x}$ & & & & & \\
\hline Myrtle & $\mathrm{x}$ & & & & & \\
\hline Moss & & & $\mathrm{x}$ & & & One bunch \\
\hline Sugar (kg) & & $\mathrm{x}$ & & & & 36,365 \\
\hline Seeds & $?$ & & $\mathrm{x}$ & & & \\
\hline Flower bulbs & & & $\mathrm{x}$ & & & \\
\hline
\end{tabular}

Amounts noted in the sound toll registers; after Tikkanen (2006) 
the most valuable goods such as indigo and brazilwood were not recovered. This might be due to their location in the cargo hold, which was not easily or safely accessible at the time when the Vrouw Maria was filling with water when the pumping failed. By combining different research methods and sources, more information about the past can be reached. The identification of plants has added significantly to the potential of archaeological interpretation and knowledge about traded items in the 1700s. Most important, it has provided evidence which would otherwise have not been acknowledged. As a result, an improved understanding of the contents of the cargo was reconstructed. Naturally, there are still gaps in our knowledge and the cargo of the Vrouw Maria partly remains a mystery. At the moment, no further sampling or additional analyses are planned, and Museovirasto (the Finnish Heritage Agency) has decided to preserve the wreck in situ.

Acknowledgements We would like to thank Mark Nesbitt from the Royal Botanic Gardens, Kew, UK for helping with analysis of legume pods and especially with indigo. Author Lempiäinen-Avci had a fruitful week at Kew, where she had access to the collections and archives for research about indigo. Furthermore, we would like to express our gratitude to experts in archaeobotany all over Europe and in India, who helped with identifications of the material from the Vrouw Maria. The final version of the manuscript has benefited from a linguistic revision by Tarja Marsh and copy editing by Riikka Elo, both from the Biodiversity Unit, University of Turku. Finally, we would like to thank associate editor Karl-Ernst Behre, reviewer Julian Wiethold and one anonymous reviewer for the fruitful advice and encouraging comments of the manuscript.

Author contributions ML-A performed the archaeobotanical analysis; TT and PH did the anatomical analysis of grasses, wood species, madder and tobacco; RA conducted the fieldwork and collected the samples from the wreck. All authors discussed the results, wrote and edited the manuscript.

Funding Open access funding provided by University of Turku (UTU) including Turku University Central Hospital. This research was funded by Kone Foundation (Grant No. 64-23764) and Turku University Foundation (Grant No. 11656) for the author Lempiäinen-Avci.

Data availability All data and presented in this study are available and open access at the botanical collections at the Herbarium, University of Turku and at the Botany Unit, Finnish Museum of Natural History, University of Helsinki.

\section{Declarations}

Conflict of interest The authors declare that they have no known competing financial interests or personal relationships that could have appeared to influence the work reported in this paper.

Open Access This article is licensed under a Creative Commons Attribution 4.0 International License, which permits use, sharing, adaptation, distribution and reproduction in any medium or format, as long as you give appropriate credit to the original author(s) and the source, provide a link to the Creative Commons licence, and indicate if changes were made. The images or other third party material in this article are included in the article's Creative Commons licence, unless indicated otherwise in a credit line to the material. If material is not included in the article's Creative Commons licence and your intended use is not permitted by statutory regulation or exceeds the permitted use, you will need to obtain permission directly from the copyright holder. To view a copy of this licence, visit http://creativecommons.org/licenses/by/4.0/.

\section{References}

Ahlström C (2000a) The Vrouw Maria of 1771: an example of documentary research. The Marine Archaeology of the Baltic Sea Area. Newsletter 1/2000, Södertörns högskola

Ahlström C (2000b) Venäjän keisarinna ja hollantilainen koffi-laiva Vrouw Maria. Nautica Fennica 2000:4-16, Vammala

Alvik R (2011) The wreck of the Vrouw Maria-A sunken treasure or a common European heritage? In: Callebaut D, Mařík J, MaříkováKubková J (eds) Heritage reinvents Europe-Proceedings of the International Conference Ename, Belgium, 17-19 March 2011. (EAC Occasional Paper 7) Europae Archaeologiae Consilium, Jambes (Namur), p 143-150

Alvik R (2012) The merchant vessels St. Michel and Vrouw Maria and their cargo. In: Ehanti E, Aartomaa J, Lounatvuori I, Tirkkonen E (eds) Lost at sea, rediscovered. Finnish National Board of Antiquities, Helsinki, pp 108-131

Alvik R (2013) Things on board: The interpretation of three 18th century shipwrecks from the Gulf of Finland. In: Rönnby J, Adams J (eds) Interpreting shipwrecks: maritime archaeological approaches. Highfield Press, Southampton, pp 119-126

Alvik R, Hautsalo V, Klemelä U, Leinonen A, Matikka H, Tikkanen S, Vakkari E (2014) The Vrouw Maria underwater project 2009_ 2012 final report. (National Board of Antiquities' Reports 2). National Board of Antiquities, Helsinki

Badura M, Możejko B, Ossowski W (2013) Bulbs of onion (Allium cepa L.) and garlic (Allium sativum L.) from the 15th-century copper wreck in Gdańsk (Baltic Sea): a part of victualling? J Archaeol Sci 40:4066-4072

Balfour-Paul J (2010) Found! A lost shipwreck! Dig (in partnership with Archaeology magazine) 12:26-29

Balfour-Paul J (2016) Indigo. Egyptian mummies to blue jeans. The British Museum Press, London

Bass GF (1987) Oldest known shipwreck reveals bronze age splendors. Nat Geogr 172:693-734

Beijerinck W (1947) Zadenatlas der Nederlandsche Flora. Mededeeling van het Biologische Instituut te Wijster 30. Wageningen, Veenman

Beneš J, Čulíková V, Kosňovská J, Frolík J, Matiášek J (2012) New plants at Prague castle and Hradčany in the early modern period: a history of selected species. Interdiscip Archaeol 3:103-114

Buchanan R (2003) A weaver's garden: growing plants for natural dyes and fibers. Dover Publications, New York

Cappers RTJ, Bekker RM, Jans JEA (2006) Digital seed atlas of the Netherlands. (Groningen Archeological Studies 4). Barkhuis Publishing, Eelde

Chenciner R (2000) Madder red: a history of luxury and trade. Routledge, London

Dafni A (2016) Myrtle (Myrtus communis) as a ritual plant in the Holy Land-a comparative study in relation to ancient traditions. Econ Bot 70:222-234

Deforce K, Allemeersch L, Stieperaere H, Haneca K (2014) Tracking ancient ship routes through the analysis of caulking material from shipwrecks? The case study of two 14th century cogs from Doel (northern Belgium). J Archaeol Sci 43:299-314 
Dodge CJG (2018) A forgotten century of brazilwood: the brazilwood trade from the mid-six-teenth to mid-seventeenth century. J Portuguese Hist 16:1-27

Einarsson L, Mörzer Bruyns WFJ (2003) A cross-staff from the wreck of the Kronan (1676). Int J Naut Archaeol 32:53-60

Eriksson N, Rönnby J (2012) 'The ghost ship'. An intact fluyt from c. 1650 in the middle of the Baltic Sea. Int J Naut Archaeol 41:350-361

Figueiral I, Bouby L, Buffat L, Petitot H, Terral J-F (2010) Archaeobotany, vine growing and wine producing in Roman Southern France: the site of Gasquinoy (Béziers, Hérault). J Archaeol Sci 37:139-149

Gale R, Cutler DF (2000) Plants in archaeology: identification manual of vegetative plant materials used in Europe and the southern Mediterranean to c. 1500. Westbury and Royal Botanic Gardens, Kew

Gelderblom O (2003) Coping with the perils of the sea: the last voyage of Vrouw Maria in 1771. Int J Marit Hist 15:95-115

Gøbel E (2010) The sound toll registers online project, 1497-1857. Int J Marit Hist 22:305-324

Haldane CW (1990) Shipwrecked plant remains. Near East Archaeol 53:55-60

Haldane CW (1993) Direct evidence for organic cargoes in the Late Bronze Age. World Archaeol 24:348-360

Hall AR (1996) A survey of palaeobotanical evidence for dyeing and mordanting from British archaeological excavations. Quat Sci Rev 15:635-640

Heimdahl J (2014) Arkeobotaniska spar efter svensk tobaksodling 1560-1775. In: Andréasson A, Gräslund Berg E, Heimdahl J, Jakobsson J, Larsson I, Persson E (eds) Sources to the history of gardening: four interdisciplinary seminars 2010-2013. (Nordic Network for the Archaeology and Archaeobotany of Gardening (NTAA) rapport 25). Sveriges Lantbruksuniversitet, Alnarp, pp 259-272

Karg S (2007) Long term dietary traditions: archaeobotanical records from Denmark dated to the middle ages and early modern times. In: Karg S (ed) Medieval food traditions in Northern Europe. (Publications from the national museum, studies in archaeology and history 12). National Museum of Denmark, Copenhagen, pp $137-159$

Kuijper W, Manders M (2009) Coffee, cacao and sugar cane in a shipwreck at the bottom of the Waddenzee, the Netherlands. Analecta Praehist Leiden 41:73-86

Leino M, Ruuskanen AT, Flinkman J, Kaasinen J, Klemelä UE, Hietala R, Nappu N (2011) The natural environment of the shipwreck Vrouw Maria (1771) in the northern Baltic Sea: an assessment of her state of preservation. Int J Naut Archaeol 40:133-150

Lempiäinen T (2006) Oulu, Kaupunginoja, Makrofossiilitutkimus: unpublished report. Biodiversity and Environmental Research Unit, University of Turku, Turku

Lewis GP (1998) Caesalpinia: a revision of the Poincianella-Erythrostemon group. Royal Botanic Gardens, Kew

Loewen B (1992) Change and diversity within traditional cooperage technology. Mater Cult Rev 36:81-90

Moolhuizen C (2009) Shipping pepper: examining botanical contents of a 17th-century shipwreck at Texel roads, the Netherlands. Analecta Praehist Leiden 41:87-96

Nakanishi F, Nagasawa Y, Kabaya Y, Sekimoto H, Shimomura K (2005) Characterization of lucidin formation in Rubia tinctorum L. Plant Physiol Biochem 43:921-928
Nesbitt M (2013) Indian dyes and textiles at the royal botanic gardens, Kew. MARG 65:100-105

Preusz M, Kodýdková K, Kočár P, Vaněček Z (2015) Exotic spices in flux: archaeobotanical material from medieval and early modern sites of the Czech Lands (Czech Republic). Interdiscip Archaeol 6:223-236

Ramsay J (2010) Trade or trash: an examination of the archaeobotanical remains from the Byzantine harbor at Caesarea Maritima, Israel. Int J Marit Archaeol 39:376-382

Robinson D, Aaby B (1994) Pollen and plant macrofossil analyses from the Gedesby ship—a medieval shipwreck from Falster, Denmark. Veget Hist Archaeobot 3:167-182

Sabato D, Masi A, Pepe C et al (2015) Archaeobotanical analysis of a bronze age well from Sardinia: a wealth of knowledge. Plant Biosyst 149:205-215

Schoute N (2017) Coopers and merchants in the Hanseatic League. A research into the marked cask components of the IJssel cog. Unpublished thesis. Maritime Archaeology, University of Southern Denmark, Esbjerg

Schweingruber FH (1990) Anatomie Europäischer Hölzer (anatomy of European woods). Haupt, Bern

Šoštarić R, Küster H (2001) Roman plant remains from Veli Brijun (island of Brioni), Croatia. Veget Hist Archaeobot 10:227-233

Tikkanen S (2006) Vrouw Maria-Selvitys tutkimuksista, tuloksista ja tulevaisuuden eri vaihtoeh-doista. Archaeology Unit, National Board of Antiquities, Helsinki

Timonen T (2011) Lausunto Vrouw Marian kasvimäärityksistä: unpublished report. Luomus, Finnish Museum of Natural History, Helsinki

Vermeersch J, Haneca K (2015) Construction features of Doel 1, a 14th-Century cog found in Flanders. Int J Naut Archaeol 44:111-131

Walton Rogers P (1997) Textile production at 16-22 Coppergate. (The archaeology of York 17: the small finds). Council of British Archaeology for the York Archaeological Trust, York

Wiethold J (2005) Botanische Funde aus der Nonnenempore des Klarissenklosters von Ribnitz, Krs. Nordvorpommern, und aus dem Haus Mönchstr. 38, Hansestadt Stralsund. Zwei Beispiele für die Auswertung und Interpretation von botanischen Funden aus Gebäuden. In: Ericsson I, Atzbach R (eds) Depotfunde aus Gebäuden in Zentraleuropa (concealed finds from buildings in Central Europe). (Bamberger Kolloquien zur Archäologie des Mittelalters und der Neuzeit 1 Archäologische Quellen zum Mittelalter 2). Scrîpvaz-Verlag, Berlin, pp 131-146

Wild A (2004) Black gold: a dark history of coffee. Harper Perennial, London

World Checklist of Vascular Plants (2021) Version 2.0. Facilitated by the Royal Botanic Gardens, Kew. http://wcvp.science.kew.org/. Accessed 23 Feb 2021

Publisher's Note Springer Nature remains neutral with regard to jurisdictional claims in published maps and institutional affiliations. 